\title{
Effects of Acid Rock Drainage on Stocked Rainbow Trout (Oncorhynchus mykiss): An In-Situ, Caged Fish Experiment
}

\author{
Andrew S. Todd • Diane M. McKnight • \\ Chris L. Jaros • Thomas M. Marchitto
}

Received: 28 January 2006 / Accepted: 28 June 2006 / Published online: 16 December 2006

(C) Springer Science + Business Media B.V. 2006

\begin{abstract}
In-situ caged rainbow trout (Oncorhynchus mykiss) studies reveal significant fish toxicity and fish stress in a river impacted by headwater acid rock drainage (ARD). Stocked trout survival and aqueous water chemistry were monitored for 10 days at 3 study sites in the Snake River watershed, Colorado, U.S.A. Trout mortality was positively correlated with concentrations of metals calculated to be approaching or exceeding conservative toxicity thresholds ( $\mathrm{Zn}$, $\mathrm{Mn}, \mathrm{Cu}, \mathrm{Cd})$. Significant metal accumulation on the gills of fish stocked at ARD impacted study sites support an association between elevated metals and fish mortality. Observations of feeding behavior and significant differences in fish relative weights between study site and feeding treatment indicate feeding and metals-related fish stress. Together, these results demonstrate the utility of in-situ exposure studies for stream stakeholders in quantifying the relative role of aqueous contaminant exposures in limiting stocked fish survival.
\end{abstract}

Keywords Acid rock drainage - Ecotoxicology In-situ exposure $\cdot$ Rainbow trout

A. S. Todd $(\bowtie) \cdot$ D. M. McKnight

C. L. Jaros $\cdot$ T. M. Marchitto

Institute of Arctic and Alpine Research,

University of Colorado,

University Campus Box 450, Boulder, CO 80309, USA

e-mail: Andrew.Todd@colorado.edu

\section{Introduction}

As a result of the large spatial extent of acid rock drainage (ARD) in the Western United States, the problem has been referred to as the greatest water quality issue facing the region (Mineral Policy Center, 1997). ARDrelated elevated metal ion concentrations, low $\mathrm{pHs}$, and metal oxide deposition limit stream biota, including microbes, algae, macroinvertebrates, and fish for many kilometers downstream of ARD sources, creating costly complications for local growth planning and the utilization of water resources (McKnight \& Feder, 1984; Todd, McKnight, \& Wyatt, 2003).

The Snake River watershed, located above Keystone, Colorado, is one example of a watershed impacted by both anthropogenic and natural inputs of ARD (Boyer et al., 1999; McKnight \& Bencala, 1990). ARD hydrological inputs originate predominantly in headwater streams, however, impacts persist many miles downstream into the resort town of Keystone (Todd, McKnight, \& Duren, 2005). Although physical and chemical environmental indicators of ARD are muted in the town of Keystone, conservative metals (e.g., Mn, Zn) remain in the water column at elevated levels (Fey, Church, Unruh, \& Bove, 2001; Todd et al., 2005). Keystone Resort stocks thousands of kilograms of rainbow trout into the Snake River each summer. These stocked trout populations do not remain in the Snake River system, and annual restocking is required to maintain this 
recreational fishery (Mitchell, 2002, personal communication). The disappearance of large numbers of stocked trout in the mainstem of the Snake River has raised concern among local stakeholders as to the mechanisms of loss. Typical limiting factors in retaining stocked trout include angling pressure, lack of suitable habitat, competition with native fish species for limited resources, and migration out of the stocking area. In this watershed, direct toxicity resulting from upstream ARD inputs is also considered a potential limiting factor.

In the present study, our goal was to investigate the role of elevated filtered metals concentrations in limiting stocked rainbow trout survival at a confluence in the Snake River ecosystem, 5+ kilometers downstream of any conspicuous indicators of acid rock drainage. To create a realistic exposure scenario that would closely replicate dynamic aqueous exposure conditions experienced by fish stocked into the Snake River, this study employed on-site, in-situ field bioassays (Chappie \& Burton, 2000). Hatchery rainbow trout were stocked in-situ in exposure cages and were monitored three times daily for fish mortality. Field measurements and filtered samples for metal analyses were taken concurrently. To quantify metal-induced stress response, half of the experimental animals were fed trout pellets throughout the experiment, and feeding behavior and changes in fish relative weight were documented. Finally, post-mortem gill tissue metals concentrations were obtained as a supporting line of evidence in the assessment of filtered metal exposure.

\section{Materials and Methods}

\subsection{Study site and sampling stations}

The Snake River Watershed is located in the Colorado Rocky Mountains near the Continental Divide (Figure 1). This study was conducted surrounding the confluence of the Snake River and the North Fork of the Snake River, both located in Summit County, Colorado.

The headwaters of the Snake River drain an area where pyrite is disseminated in rock throughout the drainage, resulting in acidic aqueous conditions ( $\mathrm{pH} 4$ ) and enrichment in dissolved metals. Below the confluence with Deer Creek, a pH neutral stream, the $\mathrm{pH}$ of the Snake River increases and the streambed is covered with precipitated metal oxides. The water quality of the Snake River again deteriorates at the confluence with Peru Creek, another large tributary. Among the many adits and tailings piles that are distributed throughout the Peru Creek basin, a significant source of ARD is the Pennsylvania Mine. Peru Creek, and a substantial reach of the Snake River below the confluence of these two rivers, have substrates covered with iron and aluminum oxides, have a low $\mathrm{pH}$, and retain elevated concentrations of dissolved metals. Both the Snake River and Peru Creek are listed on the Colorado 303(d) list of impaired waters from heavy metal contamination from abandoned mined lands.

The Snake River below Peru Creek flows for approximately $5 \mathrm{~km}$ before it meets the North Fork of the Snake River in the town of Keystone. Sections of this reach of the Snake River are characterized by high quality fish macrohabitat, with riffles, runs, and deep pools (Chadwick \& Associates, 1985). Several other long stretches of this reach are steep, boulderfilled cascades that provide limited fish habitat.

The North Fork of the Snake River (North Fork) originates near the summit of Loveland Pass and flows along U.S. Highway 6 until it drains into the Snake River in Keystone, Colorado. This stream maintains relatively high water quality along its entire length, with limited potential sources of contaminants, including highway runoff and the small ski resort, Arapahoe Basin. The North Fork is characterized by high quality in-stream trout habitat, including predominantly cobble substrate and a high occurrence of deep water formed by debris dams, undercut banks, boulders, and plunge pools. A majority of the North Fork drainage is known to support a self-sustaining, healthy brook trout fishery (Chadwick \& Associates, 1985).

Below the confluence with the North Fork, the Snake River flows through the town of Keystone, where it is utilized for diverse recreational purposes, including boating, fishing, and as a source of water for snowmaking at the drainage's second ski resort, Keystone Resort. The Snake River ultimately flows into Dillon Reservoir, a major water supply for the City of Denver. Substrate in this reach is primarily cobble, with a silt-like material filling in the interstices between cobbles. Shallow riffles, frequent pools, overhanging banks and runs define the Snake River through the town of Keystone, resulting in suitable salmonid habitat. 
Sampling sites for this study were selected to represent environmental conditions in the Snake River and the North Fork, above and below their confluence (Figure 1). The Snake River study site upstream of the North Fork (SANF) was located approximately $5 \mathrm{~km}$ from Keystone along Montezuma Road. The North Fork study site (NFS) was located along U.S. Highway 6 approximately $5 \mathrm{~km}$ upstream from Keystone. The final Snake River study site (SBNF) was located approximately $1.5 \mathrm{~km}$ below this confluence, within the town of Keystone. Stream discharges throughout this study were obtained from real-time measurements at U.S. Geological Survey Stream Gauge \#09047500.

\subsection{Bioassay period and exposure cages}

This 10-day field bioassay was conducted beginning on the afternoon of July 29th, 2003 and ending on the afternoon of August 8th, 2003. The bioassay test period was selected to occur during the summer fish stocking season, and late enough in the summer to allow the experimental fish to be exposed to waters with elevated aqueous metals concentrations, undiluted by spring snow melt.

In situ exposure cages were constructed as cubes, built with $1.27 \mathrm{~cm}$ polyvinyl chloride pipe $(61 \mathrm{~cm} \times$ $61 \mathrm{~cm} \times 61 \mathrm{~cm})$. All vertical sides were enclosed by polyethylene netting (mesh size: $13 \mathrm{~mm} \times 13 \mathrm{~mm}$ ) secured with cable ties (McKee, Ordner, Houston, \& Lawrence, 1989). Total volume of each exposure cage was approximately 225 liters. The polyethylene netting forming the bottom of the cage was extended $(\sim 30 \mathrm{~cm})$ as exterior skirting to facilitate anchoring the cage instream with rocks (Slack \& O’Connell, 1998).

At each site, four exposure cages were placed in the stream. Cages were positioned in locations that were

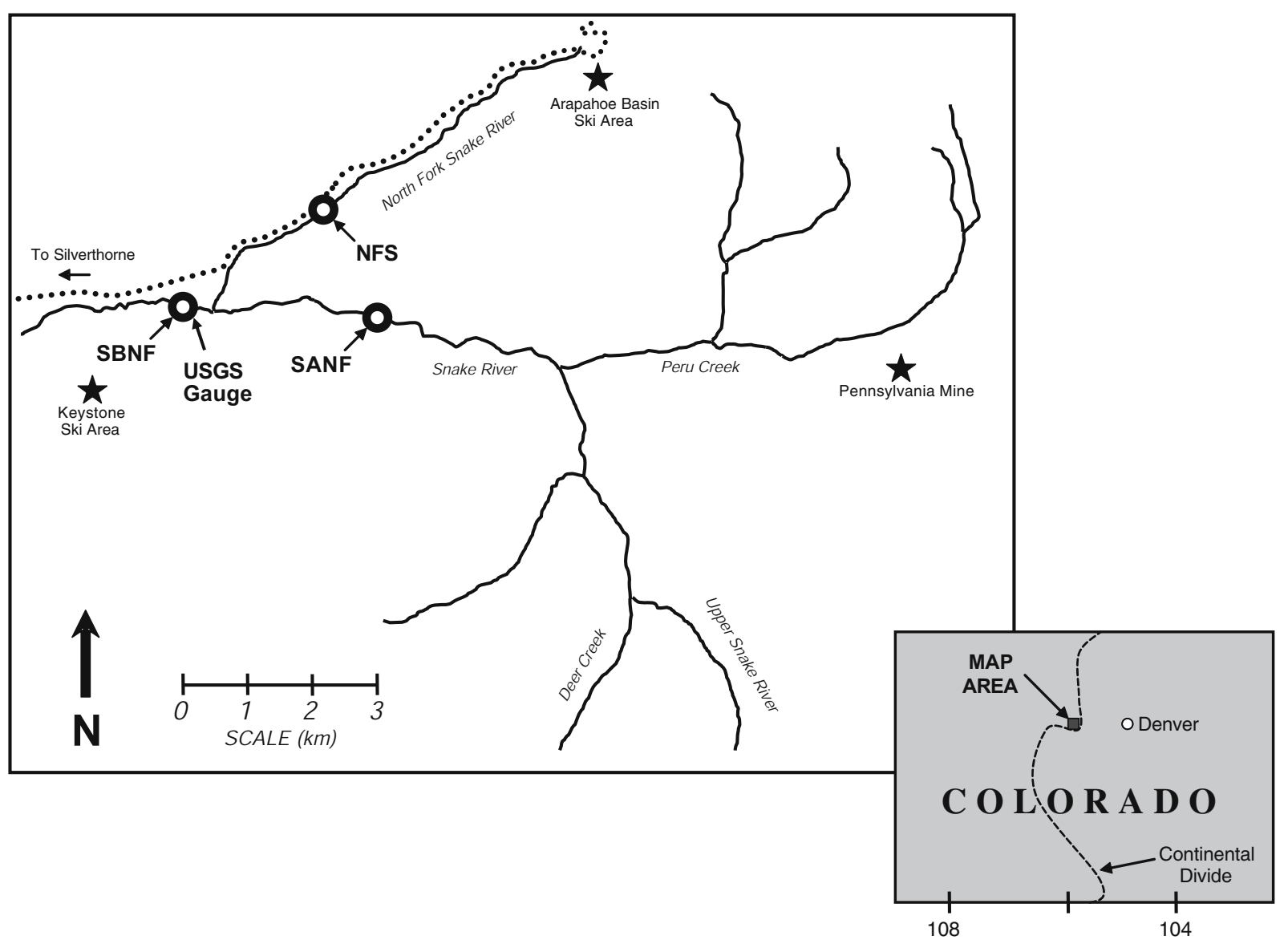

Figure 1 Diagram of the Snake River watershed, major watershed features, and study sites where fish survival and water chemistry were studied $(\mathrm{SANF}=$ Snake River upstream of the North Fork of the Snake River, NFS $=$ North Fork of the Snake River, SBNF $=$ Snake River downstream of the North Fork of the Snake River). Approximate latitude and longitude: $39^{\circ} 36^{\prime} \mathrm{N}, 105^{\circ} 57^{\prime} \mathrm{W}$. 
$50-60 \mathrm{~cm}$ in depth, with flows sufficient to regularly exchange the water volume of the cage, but slow enough so that stocked fish were not subjected to high current velocities. In summary, our experimental design comprised three study sites, with each site containing two feeding treatments with two replicate cages in each treatment. In total, 50 experimental fish made up each treatment at each site.

\subsection{Experimental fish}

Hatchery reared rainbow trout (Oncorhynchus mykiss) were obtained from the Pleasant Valley Fish Farm in McCook, Nebraska. All fish were certified whirling disease free, and were permitted by the Colorado Division of Wildlife to enter the state of Colorado for this experiment.

Fish were transported in an aerated 650-L fiberglass tank approximately 550 kilometers to Keystone, Colorado. On arrival, 300 fish were lightly anesthetized in five-gallon buckets using a dilute solution (80 mg/L) of MS222 (tricaine methane sulfonate), with the immersion time of individual fish limited to less than 10 minutes (Summerfelt \& Smith, 1990). Fish were each tagged with a custom, numbered t-bar vinyl tag, applied beneath the dorsal fin with a fine fabric gun (Guy, Blankenship, \& Nielsen, 1996). Each tagged fish was then weighed using Pesola springscales, and length was measured on a standard fish board. Initial relative weights $\left(W_{\mathrm{r}}\right)$ were calculated for all tagged fish by comparing individual initial weights with standard weights $\left(W_{\mathrm{s}}\right)$ derived according to the standard equation format for lotic rainbow trout (Anderson \& Neumann, 1996). All tagged fish were then placed into a separate aerated tank to recover overnight.

Randomly selected tagged fish were transported in five-gallon buckets to cages at each study site location. Fish were tempered with stream water for approximately 15 minutes, a time frame that would be typical of fish stocked at these locations. Following this acclimatization period, twenty-five fish (average mass: $83 \mathrm{~g}$ ) were placed into each cage, resulting in a fish-stocking density $(\sim 10 \mathrm{~g} / \mathrm{L})$ similar to other insitu, caged-fish experiments (Camusso, Vigano, \& Balestrini, 1995; Farag, Skaar, Nimick, MacConnell, \& Hogstrand, 2003; Van Sickle et al., 1996).

Following stocking, the exposure cages were revisited approximately every eight hours, in the morning
( $\sim 7$ AM), the afternoon ( 3 PM), and the evening ( $\sim 11$ PM). During each visit, cages were checked for dead or moribund fish. Fish were considered moribund when they had fully lost their equilibrium and were unresponsive to handling. Moribund fish were pithed, and all dead fish were placed in separate Ziploc bags and into a cooler under dry-ice. Surviving fish within fed experimental treatments were fed an excess of floating trout pellets during each visit, and feeding behavior was observed. On August 9th, 2003, surviving fish at all sampling sites (NFS $=100, \mathrm{SBNF}=79$, SANF $=1$ ) were pithed, bagged, and stored on dry ice. All fish were then stored in a laboratory deep freezer $\left(-10^{\circ} \mathrm{C}\right)$ at the Institute of Arctic and Alpine Research in Boulder, Colorado.

The eight longest-surviving fish at each study site were selected for gill tissue analyses. High-quality, corrosion-resistant stainless steel tools were used to dissect gill tissue from each fish, with dissection tools cleaned in between samples with an Alconox detergent solution. Gill tissue was removed from gill rakers, weighed, and re-frozen.

Gill tissue samples were dried at $65^{\circ} \mathrm{C}$ for several days to obtain a constant weight for determination of percent moisture. Dried tissue samples were placed into pre-weighed, chemically inert fluoropolymer microwave vessels with $9 \mathrm{~mL}$ nitric acid (Fisher Trace Metal Brand), and then digested using closed-vessel microwave digestion. For quality control purposes, National Research Council of Canada DORM-2 Dogfish muscle tissue was digested concurrently with gill tissue samples. A nitric acid analytical blank was included in each of the two digestion sets. Final digestion sample matrix was approximately $9 \%$ nitric acid. Concentrations of trace metals in gill tissue samples were measured in the laboratory using a Thermo Finnigan Element2 inductively coupled plasma mass spectrometer (ICP-MS). All samples, including analytical blanks, reference tissue exudates, and gill tissue exudates were subjected to a ten-fold dilution prior to ICP-MS analysis.

\subsection{Water chemistry}

During the exposure period, water quality samples and associated measurements were taken concurrently with fish visits. Grab samples for inorganic analyses were collected in acid-washed 1-L plastic bottles that had been rinsed three times with stream water. $\mathrm{pH}$, 
a.

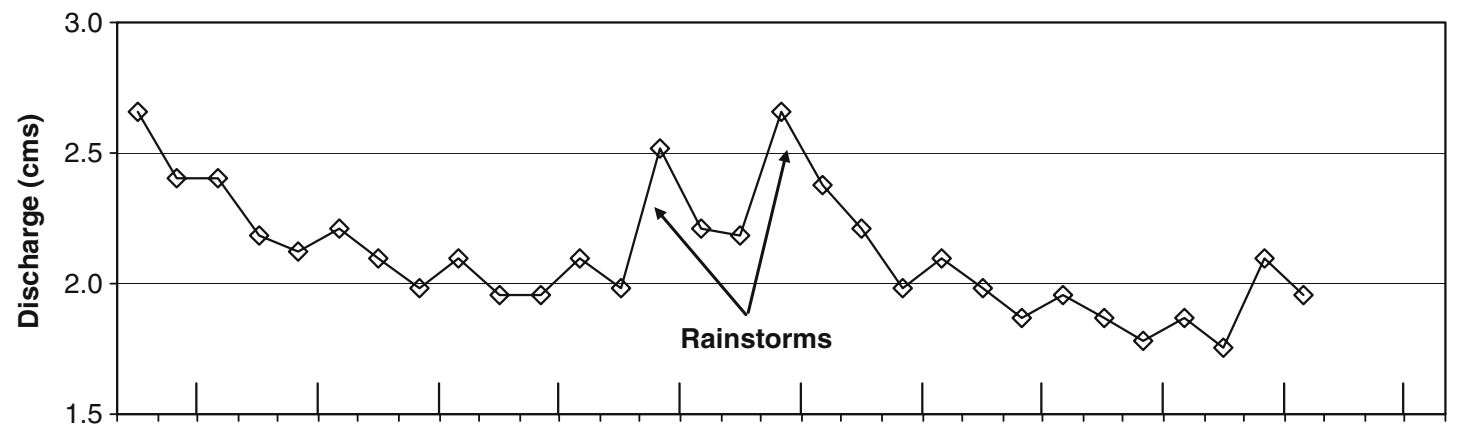

b.

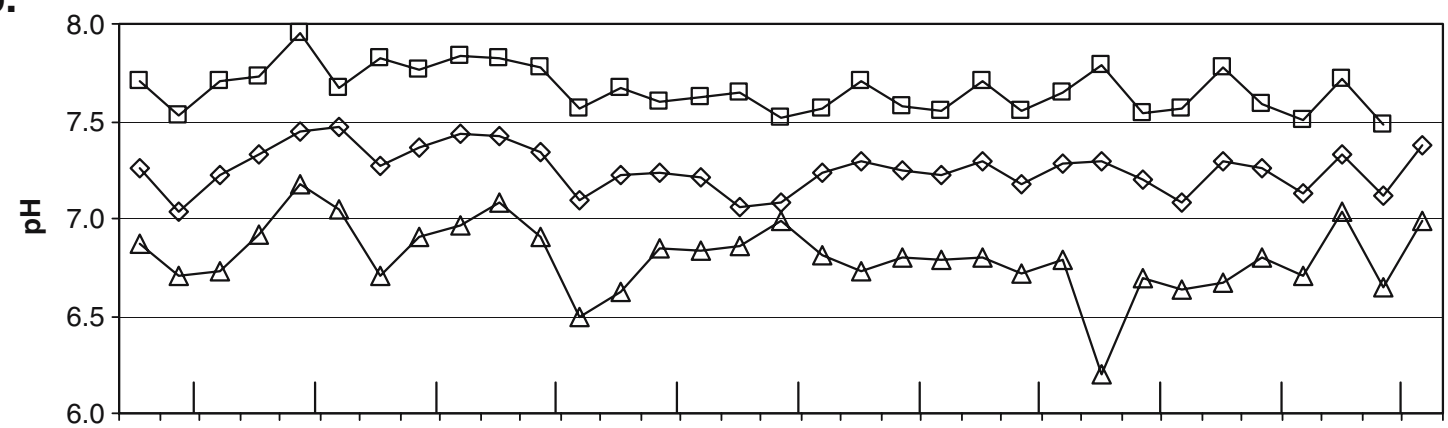

C.

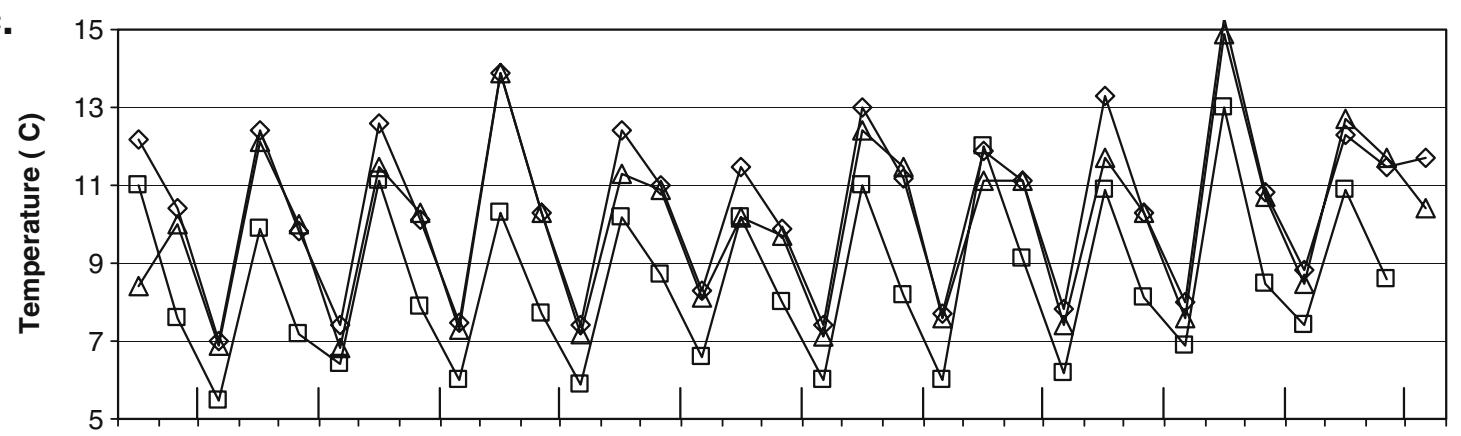

d.

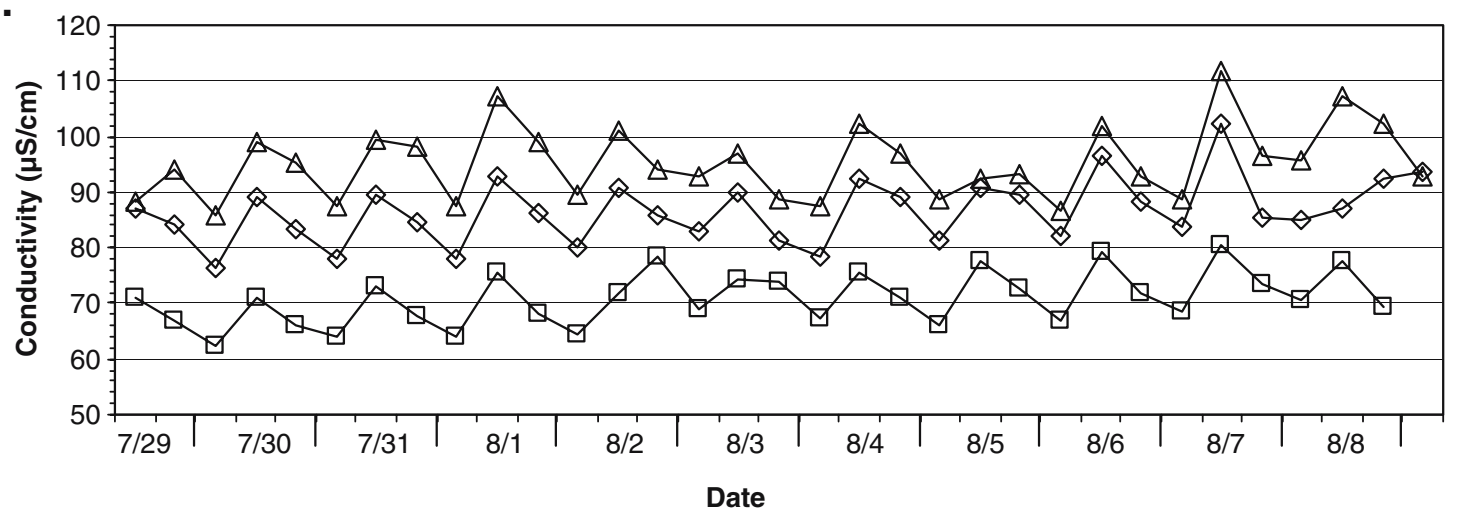

North Fork Snake River $\triangle$ Snake River above North Fork $\diamond$ Snake River below North Fork

Figure 2 Water quality parameters as measured during in-situ trout exposure experiment, July 29th-August 8th, 2003. Discharge measurements (a) were obtained from USGS Stream Gauge 09047500. 


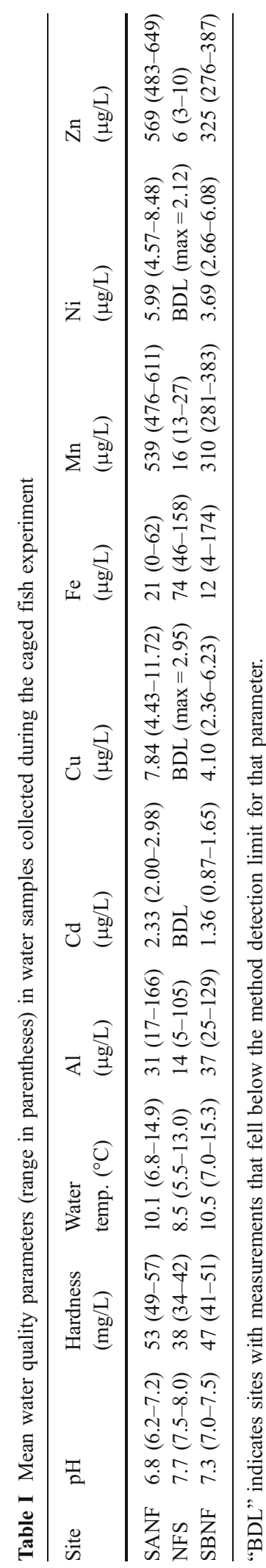

conductivity, and water temperature were measured using a YSI 63 multimeter. Samples were filtered through $0.4-\mu \mathrm{m}$ Nucleopore filters into acid-washed 120-mL plastic bottles. Samples for cation and filtered metals analysis were acidified using $0.5-\mathrm{mL}$ concentrated Ultrex nitric acid. Cation and filtered metal concentrations were measured in the laboratory using a Jarrel-Asch Inductively Coupled Plasma spectrometer (ICP-AES).

\subsection{Data analysis, modeling, and statistical tests}

To assess theoretical, relative risk to an aquatic organism, calculation of hazard quotients (HQ) was employed (USEPA, 1997). This calculation is defined as the exposure concentration divided by the effect concentration. For this conservative scenario, effect concentration values were set as U.S. Environmental Protection Agency's (USEPA) hardness-corrected acute Ambient Water Quality Criteria values (USEPA, 2002), as the acute value is most representative of risks from short term exposures to contaminants. An HQ of greater than 1 indicates potential risk to the organism, while an HQ of less than 1 indicates minimal risk to the organism from that individual contaminant. Since the AWQC values are a general value that is used nationwide, and may be influenced by sensitive aquatic species not present in this ecosystem, effect concentrations specific to rainbow trout were also investigated. Toxicity of metal mixtures was not considered in this study.

Speciation of select metals was modeled at the SANF and SBNF study sites using Visual MINTEQ Version 2.32, a Windows version of MINTEQA2 ver 4.0 (HydroGeoLogic \& Allison Geoscience Consultants, 1999). Measured mean values were used as input values for metals of concern for fish toxicity $(\mathrm{Cd}, \mathrm{Cu}, \mathrm{Mn}, \mathrm{Zn})$ and other relevant ions (Ca and $\mathrm{Mg}$ ). Modelled $\mathrm{pH}$ was fixed at 6.8 and 7.3 , averages for the SANF and SBNF study sites, respectively. Because the alkalinity of waters in the Snake River watershed is naturally quite low, for these model runs, aqueous carbonate species were assumed to be at equilibrium for the measured $\mathrm{pH}$ with the atmospheric partial pressure of $\mathrm{CO}_{2}$ at the elevation of the site. Approximate sulfate, chloride and DOC concentrations were used from a previous study with study sites in close proximity to SANF and SBNF. The August sampling date within this 2002 study had flow rates 
a.

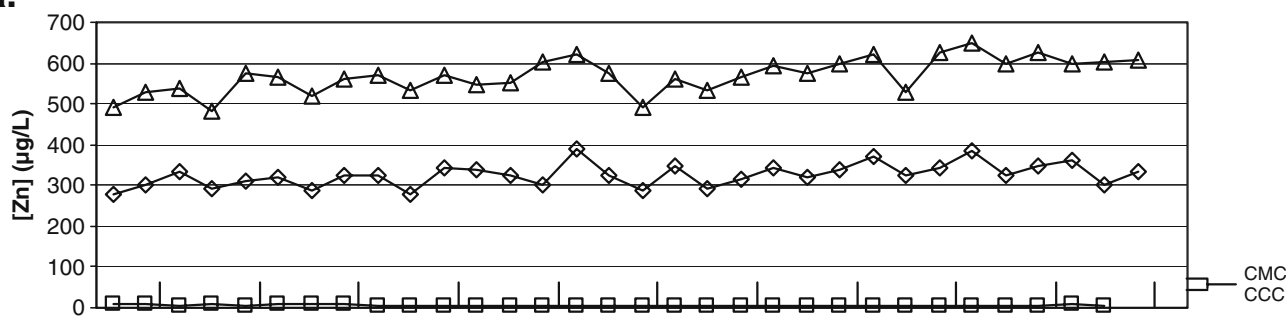

b.

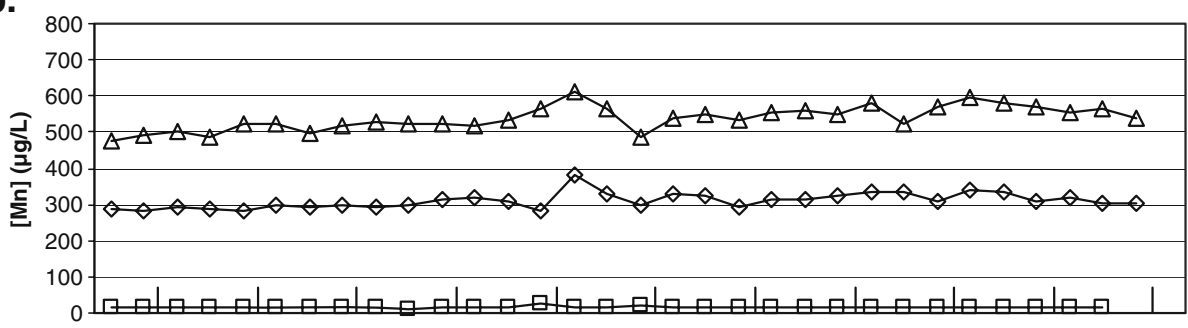

c.

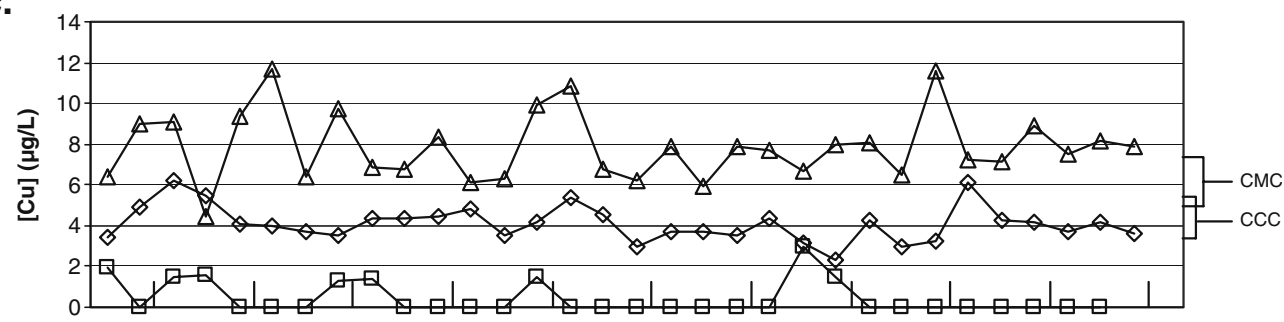

d.

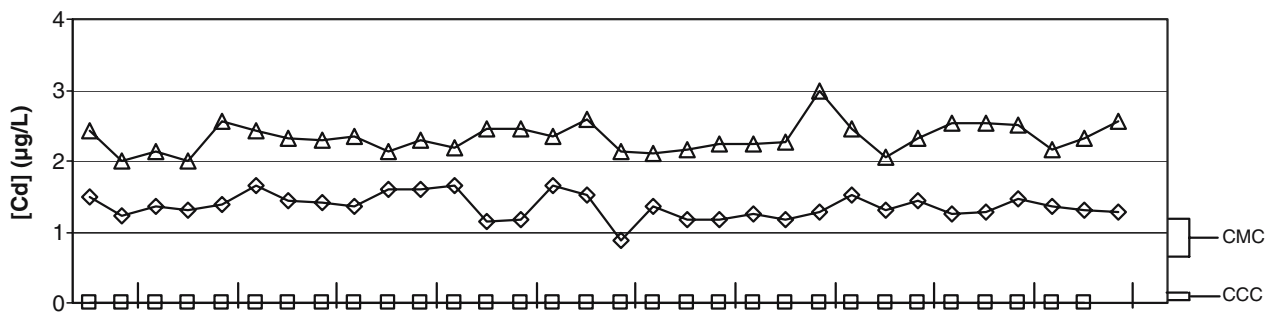

e.

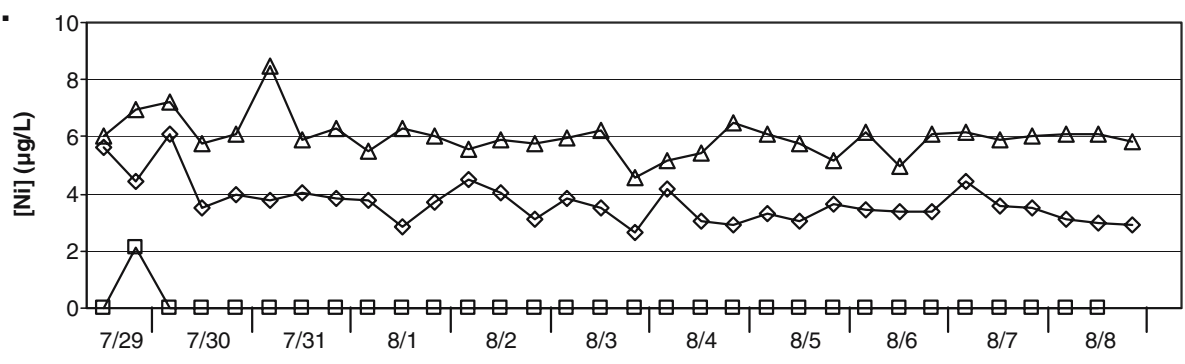

North Fork Snake River $\triangle$ Snake River above North Fork $\diamond$ Snake River below North Fork

Figure 3 Filtered metal concentrations as measured during insitu trout exposure experiment, July 29th-August 8th, 2003. Toxic filtered metal criteria for aquatic life, as defined by the Ambient Water Quality Criteria vary with varying hardness at each site (USEPA, 2002). For illustrative purposes, the calculated range of variability for acute and chronic toxicity thresholds across all three experimental sites is depicted as brackets on the right-hand margin of the figure. The Criteria
Maximum Concentration (CMC) is an estimate of the highest concentration of a material in surface water to which an aquatic community can be exposed briefly without resulting in an unacceptable effect. The Criterion Continuous Concentration (CCC) is an estimate of the highest concentration of a material in surface water to which an aquatic community can be exposed indefinitely without resulting in an unacceptable effect (EPA, 2002). 
$(\sim 1.42 \mathrm{cms})$ and ion concentrations comparable to this study (Belanger, 2002). Finally, approximate filtered $\mathrm{Pb}$ concentrations were obtained from another prior study with study sites in close proximity to SANF and SBNF (2.7 and $0.3 \mu \mathrm{g} / \mathrm{L}$, respectively) (Fey et al., 2001).

All statistical tests conducted in this study employed the Windows SPSS 13.0 software package. Observed trends in individual metal chemistry were correlated with observed fish mortality rates to identify preliminary metals of concern. Paired and independent samples $t$-tests were employed to compare initial and final relative weights of fish at each site and treatment. Box plots depicting metals concentrations of fish gill tissues were created, and the significance of differences between gill tissue metal concentrations were determined using MannWhitney U tests. Finally, Cox regression analyses were utilized to compare fish mortality rates between study sites. A graphical estimate of the $\mathrm{LT}_{50}$, the time within which river water caused the deaths of $50 \%$ of the experimental fish population, was made at the SANF study site.

\section{Results}

\subsection{Water chemistry}

The experimental period was characterized by stable flow conditions, with daily mean streamflow ranging from 1.81 to $2.55 \mathrm{cms}$. A significant rainstorm occurred on the evening of August 2nd, 2003, increasing streamflow from 2.10 to $2.52 \mathrm{cms}$ in less than $12 \mathrm{~h}$ (Figure 2a). A second storm on the afternoon of August 3rd, 2003 raised streamflow from 2.18 to $2.66 \mathrm{cms}$ within a similar time frame (Figure 2a). Neither rainfall event resulted in significant changes in water elevation within experimental cages. Field water quality parameters collected during this study are summarized in Table I, and depicted in Figure 2. In general, all three study sites were characterized by relatively soft waters, circumneutral $\mathrm{pHs}$, and water temperature fluctuations typical of mountain streams. In general, filtered metal levels were highest at the SANF study site, lowest at the NFS study site, and moderate at the SBNF study site (Figure 3). Filtered iron levels did not follow this

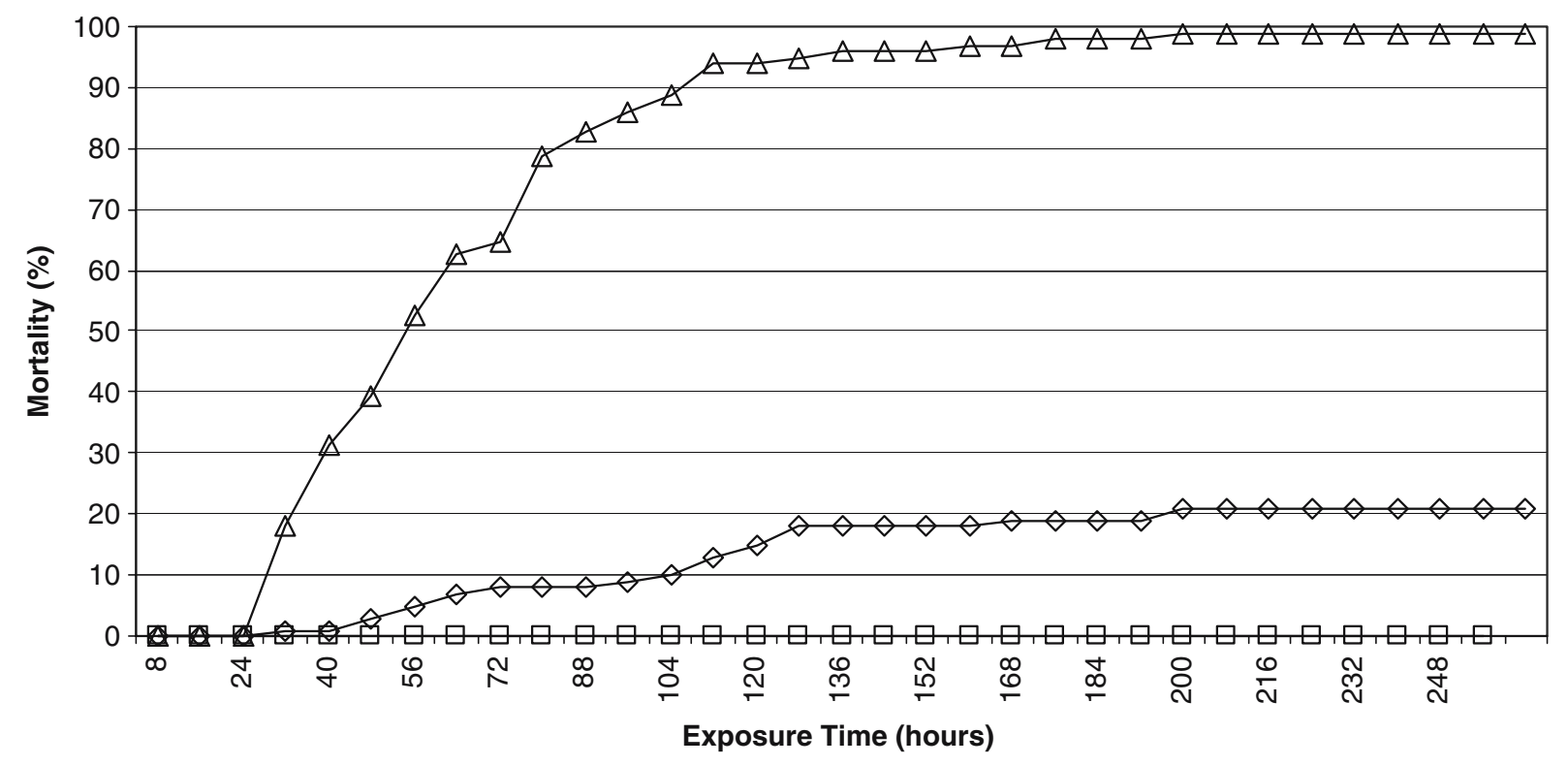

North Fork Snake River Snake River above North Fork Snake River below North Fork

Figure 4 Mortality of stocked rainbow trout during 10-day exposure conducted July 29th-August 9th, 2003 at instream sites located near the confluence of the Snake River and the North Fork of the Snake River. Significant mortality $(p<0.01)$ was observed at the SANF study site $(99.0 \%)$, at the SBNF study site $(21.0 \%)$ over the 10 -day exposure period. Significant ( $t$-test) differences in fish survival were observed between the SANF and both the NFS and SBNF after $24 \mathrm{~h}$ $(p<0.001)$ while differences between NFS and SBNF became significant after $56 \mathrm{~h}(p=0.05)$. 
Table II Mean initial and final relative weights by site and experimental treatment

\begin{tabular}{|c|c|c|c|c|c|}
\hline Site & Treatment & Initial $W_{\mathrm{r}}$ & Final $W_{\mathrm{r}}$ & $\begin{array}{l}\text { Paired difference } \\
\text { Final } W_{\mathrm{r}}-\text { Initial } W_{\mathrm{r}}\end{array}$ & Net difference ${ }^{\mathrm{b}}$ Fed vs Unfed \\
\hline SANF & $\begin{array}{l}\text { Fed } \\
\text { Unfed }\end{array}$ & $\begin{array}{l}99.8 \\
101.7\end{array}$ & $\begin{array}{l}104.8 \\
107.1\end{array}$ & $\begin{array}{l}5.01(3.80,6.23) \\
5.38(4.07,6.70)^{\mathrm{c}}\end{array}$ & $0.37(-2.14,1.40)$ \\
\hline NFS & $\begin{array}{l}\text { Fed } \\
\text { Unfed }\end{array}$ & $\begin{array}{l}96.5 \\
99.9\end{array}$ & $\begin{array}{l}110.3 \\
95.9\end{array}$ & $\begin{array}{l}13.80(11.19,16.40) \\
-4.00(-4.70,-3.29)^{\mathrm{c}, \mathrm{d}}\end{array}$ & $17.79(15.13,20.48)$ \\
\hline SBNF & $\begin{array}{l}\text { Fed } \\
\text { Unfed }\end{array}$ & $\begin{array}{l}101.9 \\
98.3\end{array}$ & $\begin{array}{l}110.7 \\
99.8\end{array}$ & $\begin{array}{l}8.77(4.91,12.63) \\
1.50(-0.87,3.86)^{\mathrm{d}}\end{array}$ & $7.27(2.79,11.76)$ \\
\hline
\end{tabular}

Differences in relative weight (95\% confidence interval) are presented for comparisons between initial and final relative weights at each site and treatment, fed vs. unfed at each site, and between unfed groups between each contaminated experimental site and the reference site.

${ }^{\text {a }}$ Paired $t$-test.

${ }^{\mathrm{b}}$ Independent samples $t$-test.

${ }^{\mathrm{c}}$ Net difference by independent samples $t$-test: 9.38 (95\% CI: 7.90, 10.85).

pattern, as levels of this metal were highest at the NFS study site. Mean filtered aluminum concentrations were similar at all sites, and all sites demonstrated a wide range of aluminum concentrations.

\subsection{Fish mortality}

Significant mortality $(p<0.01)$ was observed at the SANF study site $(99.0 \%)$ and at the SBNF study site $(21.0 \%)$ over the 10-day exposure period. Significant $(t-$ test) differences in fish survival were observed between the SANF and both the NFS and SBNF after $24 \mathrm{~h}$ $(p<0.001)$ while differences between NFS and SBNF became significant after $56 \mathrm{~h}(p=0.05)$ (Figure 4). Many dying fish at both SANF and SBNF study sites were observed drifting in their cages, unable to maintain equilibrium. No evidence of size-selective mortality was observed at either the SANF or SBNF sites.

\subsection{Experimental fish fitness and feeding observations}

Tagged, experimental fish had a mean (S.D., $n$ ) length of $196 \mathrm{~mm}(20,297)$ and a mean initial wet weight of $83.7 \mathrm{~g}(25,297)$. Experimental fish had a mean initial relative weight of $99.7(7.6,295)$ (Table II). Final wet weights, measured following fish death or pithing, were utilized with recorded fish lengths to calculate final relative weights for fish from fed and unfed treatments at all study sites (Table II).

Fish at the reference NFS site demonstrated a large, significant difference between fed and unfed treat- ments; fish that were routinely fed increased in relative weight $(+13.80 \pm 2.61)$ over the course of the experiment while the unfed group had decreased relative weights $(-4.00 \pm 0.70)$. In contrast, at the most contaminated SANF site, both fed and unfed fish had higher relative weights $(+5.01 \pm 1.20$, $+5.38 \pm 1.31)$ following the experiment, and the slight observed differences between average relative weights between the treatments were insignificant. Fed fish in the downstream SBNF site demonstrated significantly higher relative weights following the experiment $(+8.77 \pm 3.86)$; unfed fish at this site saw a significantly smaller increase in relative weight $(+1.50 \pm 2.36)$.

Fed fish at the NFS study site and the SBNF study site were regularly observed to consume trout pellets at each feeding, while fed fish at the SANF study site were rarely observed surfacing to the floating trout food.

\subsection{Fish gill tissue analysis}

Significantly elevated concentrations of $\mathrm{Cu}$ and $\mathrm{Pb}$ were observed in gill tissue samples of rainbow trout from the SANF and SBNF study sites when compared with the reference NFS study site (Figure 5a,b). Variations in gill tissue concentrations of $\mathrm{Zn}$ were not significant between experimental study sites (Figure 5c). Finally, gill $\mathrm{Cd}$ concentrations were significantly altered at both ARD-impacted study sites; in this case, the moderately impacted SBNF 
a)

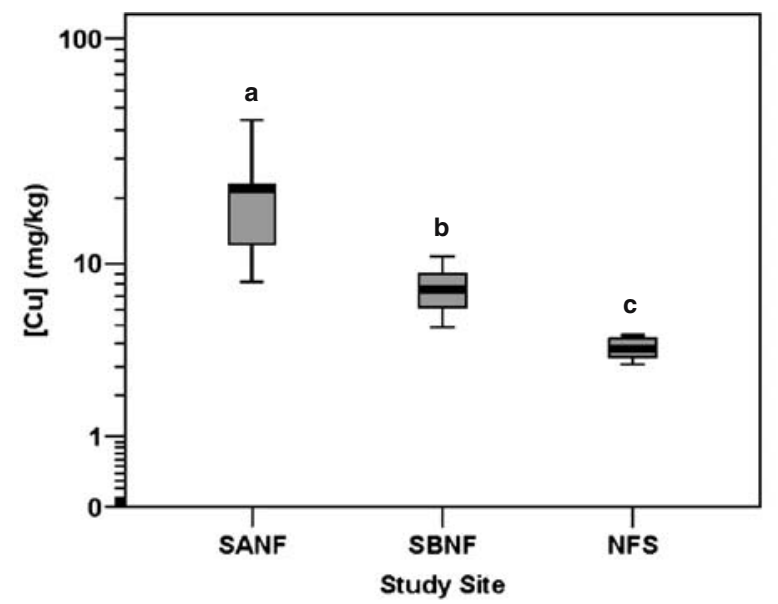

c)

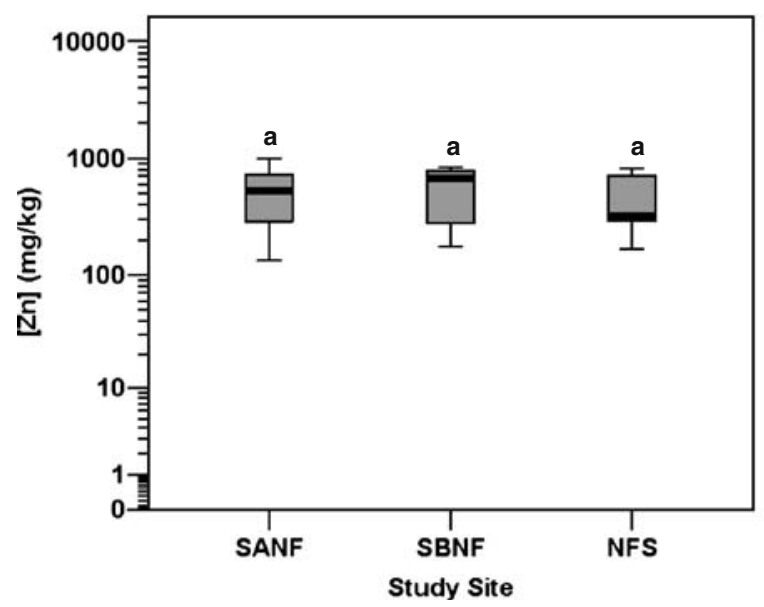

Figure 5 Gill tissue metal concentrations as measured during Snake River in-situ trout exposure experiment, July 29thAugust 8th, 2003. Dark lines across boxes represent median values, boxes contain values falling within 25 th and 75 th

study site demonstrated the highest gill tissue $\mathrm{Cd}$ concentrations (Figure 5d).

\subsection{MINTEQ modeling}

The chemical speciation of key component metals at SANF and SBNF, as calculated using Visual MINTEQ Version 2.32, is presented in Table III. Metal speciation analyses examine the "solution state" of metals of interest, as the state of the metal can influence its availability and toxicity to aquatic organisms. Dominant species (by percentage of total component concentration) for all component metals b)

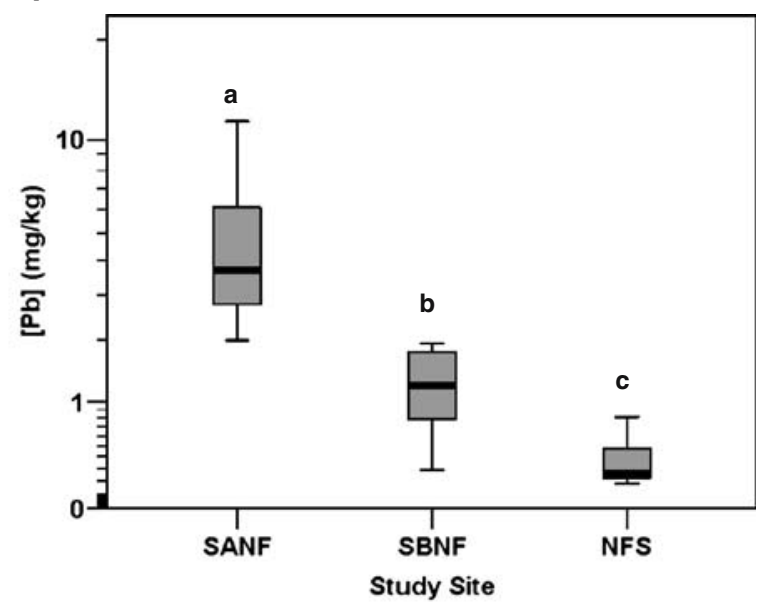

d)

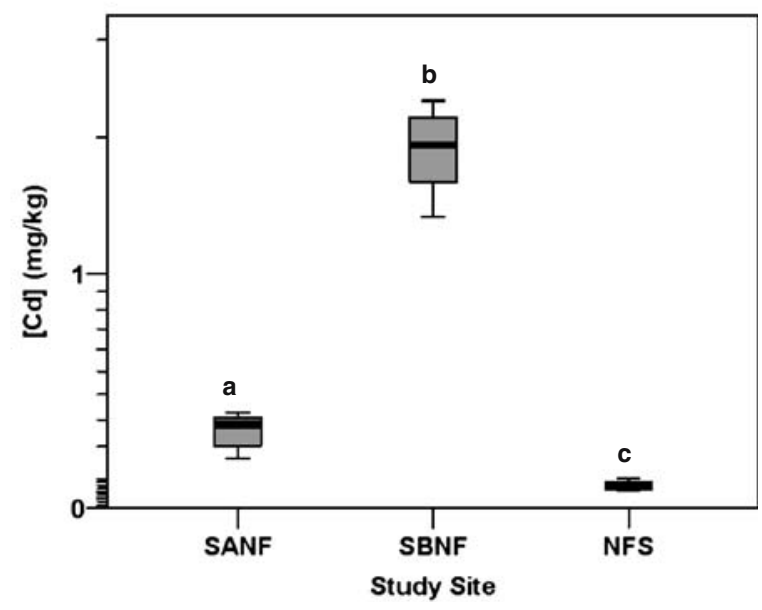

percentiles, and bars define the full extent of the range of measured values. For each metal, box plots with the same letter are not significantly different (Mann-Whitney, $p<0.036$ ).

include the free ion, the DOC-complexed metal, and complexes with sulfate, carbonate and hydroxide ions $\left(\mathrm{SO}_{4}^{2-}, \mathrm{CO}_{3}^{2-}\right.$ and $\left.\mathrm{OH}^{-}\right)$. Differences between the complexation behavior of individual metals are evident at both study sites; a significant fraction of $\mathrm{Pb}$ and $\mathrm{Cu}$ ions are predicted to exist bound to DOM, while $\mathrm{Cd}, \mathrm{Mn}$, and $\mathrm{Zn}$ are calculated to be primarily in the free ionic state. In general, comparison between the SANF and SBNF sites predicts that downstream increases in DOC concentration and $\mathrm{pH}$, coupled with dilution of component metal concentrations, results in increased ratio of bound $\mathrm{Cu}$ and $\mathrm{Pb}$ ions, relative to free ion metal. 
Table III Results of speciation modeling exercise using Visual MINTEQ ver. 2.32, a Windows version of MINTEQA2 ver. 4.0 (HydroGeoLogic \& Allison Geoscience Consultants, 1999)

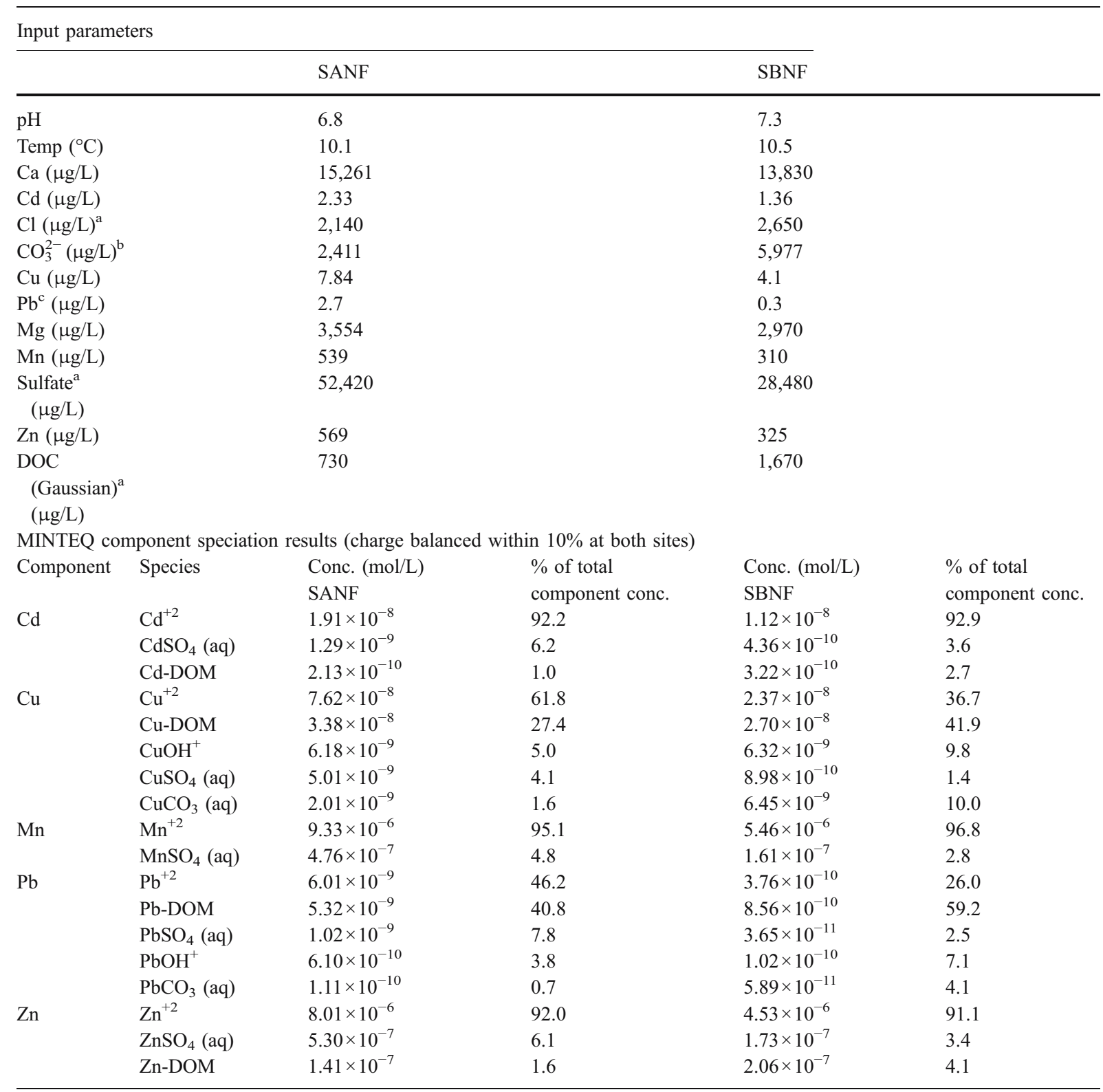

${ }^{\mathrm{a}}$ Values from Belanger (2002).

${ }^{\mathrm{b}}$ Because the alkalinity of waters in the Snake River watershed is naturally quite low, for these model runs, aqueous carbonate species were assumed to be at equilibrium for the measured $\mathrm{pH}$ with the atmospheric partial pressure of $\mathrm{CO}_{2}$ at the elevation of the site, resulting in the total concentrations listed above.

${ }^{\mathrm{c}}$ Values from Fey et al. (2001). 
Table IV Hazard quotients calculated for Rainbow Trout

\begin{tabular}{|c|c|c|c|c|c|c|}
\hline Site & Metal & $\begin{array}{l}\text { Mean [Metal] } \\
(\mathrm{ppb})\end{array}$ & $\begin{array}{l}\text { AWQC CMC } \\
(\mathrm{ppb})^{\mathrm{a}}\end{array}$ & $\begin{array}{l}\text { Rainbow Trout (RT) } \\
(\mathrm{ppb})^{\mathrm{b}}\end{array}$ & $\begin{array}{l}\text { Calculated HQ } \\
\text { (AWQC) }\end{array}$ & $\begin{array}{l}\text { Calculated HQ (RT } \\
\text { Specific) }\end{array}$ \\
\hline \multirow[t]{7}{*}{ SANF } & $\mathrm{Al}$ & 31 & 750 & 750 & 0.0 & 0.0 \\
\hline & $\mathrm{Cd}$ & 2.3 & 1.1 & 1.9 & 2.1 & 1.2 \\
\hline & $\mathrm{Cu}$ & 7.9 & 7.1 & 54 & 1.1 & 0.2 \\
\hline & $\mathrm{Fe}$ & 21 & $1,000^{\mathrm{c}}$ & - & 0.0 & - \\
\hline & $\mathrm{Mn}$ & 540 & - & 3,320 & - & 0.2 \\
\hline & $\mathrm{Ni}$ & 6.0 & 270 & - & 0.0 & - \\
\hline & $\mathrm{Zn}$ & 570 & 63 & 321 & 9.0 & 1.8 \\
\hline \multirow[t]{7}{*}{ SBNF } & $\mathrm{Al}$ & 37 & 750 & 750 & 0.0 & 0.0 \\
\hline & $\mathrm{Cd}$ & 1.4 & 1.0 & 1.9 & 1.4 & 0.7 \\
\hline & $\mathrm{Cu}$ & 4.1 & 6.3 & 54 & 0.7 & 0.1 \\
\hline & $\mathrm{Fe}$ & 12 & $1,000^{\mathrm{c}}$ & - & 0.0 & - \\
\hline & $\mathrm{Mn}$ & 310 & - & 3,320 & - & 0.1 \\
\hline & $\mathrm{Ni}$ & 3.7 & 244 & - & 0.0 & - \\
\hline & $\mathrm{Zn}$ & 330 & 57 & 321 & 5.8 & 1.0 \\
\hline
\end{tabular}

The Criteria Maximum Concentration (CMC) is an estimate of the highest concentration of a material in surface water to which an aquatic community can be exposed briefly without resulting in an unacceptable effect, as defined by the Ambient Water Quality Criteria (USEPA, 2002).

${ }^{a}$ Values calculated from USEPA (2002) using the mean hardness value at each study site (SANF $=53 \mathrm{mg} / \mathrm{L} ; \mathrm{SBNF}=47 \mathrm{mg} / \mathrm{L}$ ).

${ }^{\mathrm{b}}$ Data compiled by Horn (2001) for waters with water hardness $<50 \mathrm{mg} / \mathrm{L}$.

${ }^{c}$ AWQC CCC value. The Criterion Continuous Concentration (CCC) is an estimate of the highest concentration of a material in surface water to which an aquatic community can be exposed indefinitely without resulting in an unacceptable effect (USEPA, 2002).

\subsection{Hazard quotient analysis}

To establish a causal relationship between filtered metals and fish mortality at contaminated sites, metals concentrations observed during this exposure period were compared to water quality criteria for metals of concern. At the SANF study site, both $\mathrm{Cd}$ and $\mathrm{Zn}$ exceeded the range of hardness-corrected EPA acute toxicity criteria throughout the exposure period (Figure 3a,d). Filtered copper concentrations frequently exceeded the range of corrected acute AWQC criteria at this study site (Figure 3c). At the downstream SBNF study site, filtered $\mathrm{Zn}$ and Cd exceeded ranges of EPA's hardness-corrected acute criteria. Hazard quotients calculated based on mean metal concentrations and EPA hardness-corrected acute criteria suggest that filtered $\mathrm{Zn}$ is the primary contaminant of concern for acute fish toxicity at both AMD-impacted Snake River study sites, and that filtered $\mathrm{Cd}$ and $\mathrm{Cu}$ also likely contribute to acute toxicity (Table IV). Hazard quotient calculations based on rainbow trout specific toxicity criteria also show that $\mathrm{Zn}$ and $\mathrm{Cd}$ as filtered metals have the potential to cause acute rainbow trout toxicity at these sites (Table IV). Very low HQs for Mn and Ni suggest that these metals do not play a primary role in limiting stocked fish survival at these study sites (Table IV).

\section{Discussion}

\subsection{Water chemistry and stocked fish mortality}

The association between study site water chemistry measurements and observed experimental fish mortality rates supports the hypothesis that filtered metal concentrations limited the survival of stocked rainbow trout populations in these sections of the Snake River. This relationship was consistent, as fish stocked in the stream reach with the highest filtered metals concentrations (SANF) had higher mortality rates than fish at study sites with either negligible (NFS) or moderate (SBNF) filtered metals concentrations. Further, one of the behavioral responses known in $\mathrm{Zn}$ toxicity is the inability to compensate for torque in a rotating water current, which was observed in moribund fish (Sorensen, 1991). 
Several factors known to influence metal toxicity in fish must be considered when predicting rates of fish mortality given concentrations of aqueous metals. Initially, cations that define the hardness of a water body, $\mathrm{Mg}^{2+}$ and $\mathrm{Ca}^{2+}$, have been observed to compete with metal ions for those binding sites where the metals exert a toxic effect (Zitko \& Carson, 1976). In this manner, streams with higher hardness can better mitigate the toxicity of filtered metals to fish within those streams (Hansen et al., 2002). Stream waters at Snake River study sites were calculated to be relatively soft (34-57 mg/L $\mathrm{CaCO}_{3}$ ), limiting mitigation potential. Similarly, dissolved organic carbon (DOC) has been observed to reduce metal toxicity through the formation of organic/metal complexes that are less bioavailable to fish (Playle, Dixon, \& Burnison, 1993). Year-round measurements of water quality parameters demonstrate routinely low DOC concentrations $(<2 \mathrm{mg} / \mathrm{L})$ at both ARD-impacted sites in this study (Todd et al., 2005). Taken together, low hardness and low DOC concentrations in the Snake River increase the potential for elevated metals concentrations to lead to toxic effects in fish.

In the process of establishing biological thresholds or toxicity criteria for specific aquatic organisms, contaminants are generally investigated without consideration of other contaminants present within the mixture. In reality, interactions between filtered metal species can influence resultant mixture toxicity, with additive, synergistic, or antagonistic toxicity implications. For instance, $\mathrm{Cu}-\mathrm{Zn}$ mixtures were demonstrated to cause both additive and synergistic toxicities in exposure studies utilizing rainbow trout, depending on water hardness (Sorensen, 1991). These types of interactions between dissolved metals species are an important consideration in investigations of ARD receiving streams, as discharges from ARD sources are typically characterized by complex mixtures of dissolved metals. Trout in this study were exposed to combinations of dissolved metals, and while HQ calculations function to identify relative risks from isolated metal exposures, the cumulative risk to the stocked fish results from the metal mixture. As such, actual risk to stocked trout may be underestimated by this simplified assessment. Multi-metal scenarios have been identified as one of the key future challenges in modeling the toxicity of contaminant mixtures to aquatic organisms (Paquin et al., 2002).

\subsection{Gill tissue metal residues as evidence}

Aquatic biota are known to retain and accumulate filtered heavy metals from their environment, with levels of uptake dependent on both exposure concentration and duration (Heath, 1987). Tissue metal residue concentrations have been used, in conjunction with observations of fish behavior or health, as lines of evidence in weight-of-evidence studies aiming to shed light on observed ecosystem impairments (Farag, Stansbury, Hogstrand, MacConnell, \& Bergman, 1995; Marr, Bergman, Lipton, \& Hogstrand, 1995). The tendency of gill tissue to reflect elevated filtered metal concentrations within the surrounding aqueous environment make analysis of gill tissue a valuable tool in identifying risks to individual fish (Grosell \& Wood, 2002; Reid \& McDonald, 1991).

In the 10-day experimental exposure period of this study, measurements of metals bound to gill tissue were obtained to identify site-specific differences in levels of accumulation. While physiological modes of fish toxicity for aqueous metals are not restricted to toxic action in gill tissue, fish mortality can result from lethal acid-base and other ion-regulatory imbalances initiated at the gill by interaction with metals (Paquin et al., 2002; Wepener, van Vuren, \& du Preez, 2001). As such, while elevated concentrations of gillbound metals identified in this study have not been causatively linked to the observed trout mortality, they serve as additional evidence linking observed fish mortality to stream water chemistry.

\subsubsection{Cu}

Exposure to elevated concentrations of filtered copper in the water has been consistently demonstrated to lead to increased levels of bound copper on fish gill tissues (Avenant-Oldewage \& Marx, 2000; Dethloff, Schlenk, Hamm, \& Bailey, 1999; Farag et al., 1995; Wepener et al., 2001). In an attempt to simplify the modeling of metal binding to diverse biotic ligands resident on fish gills, researchers have considered gill tissue as homogenous, and defined specific metal equilibrium binding constants, or $K_{\mathrm{M} \text {-Gill }}$ (Bell, Ogden, \& Kramer, 2002). The higher the value of $K_{\mathrm{M} \text {-Gill }}$ for a particular metal, the more tightly that metal will be bound to the gill. For filtered copper, a $K_{\text {Cu-Gill }}$ of 7.4 indicates that copper binds fairly strongly to gill tissue (Playle et al., 1993). This strong 
interaction between filtered copper ions and gill tissue is reflected in significant, site-specific differences in gill-bound $\mathrm{Cu}$ concentrations observed in this study (Figure 5a).

\subsection{2 $\mathrm{Pb}$}

Although not measured as a part of this study, elevated levels of filtered lead have been documented in the tributaries and upper reaches of the Snake River, including sites near the SANF study site (Fey et al., 2001). Experimentally calculated conditional equilibrium binding constants $\left(K_{\mathrm{Pb} \text {-Gill }}=6.0\right)$ indicate that this binding is relatively strong, when compared to its analog, calcium $\left(K_{\mathrm{Ca}-\text { Gill }}=4.5\right)$ (Macdonald, Silk, Schwartz, \& Playle, 2002; Playle, 2004). Data from this study demonstrate significantly elevated gill binding of lead at study sites with elevated filtered metal levels (Figure 5b). Again, while elevated levels of lead in gill tissues are not specifically linked to observed mortality rates in this study, site-specific differences in relative accumulation of lead provide additional evidence linking measured water chemistry values to fish impairment and death.

\subsubsection{Zn}

Despite elevated aqueous concentrations of $\mathrm{Zn}$ in the streamwater of the SANF and SBNF study sites, gill Zn concentrations were not significantly elevated in experimental fish stocked at these sites when compared with the reference NFS study site (Figure 5c). Many researchers have demonstrated a similar lack of correlation between elevated concentrations of filtered $\mathrm{Zn}$ and concentrations of $\mathrm{Zn}$ in the exposed gill tissues (Camusso et al., 1995; Dethloff et al., 1999; Farag, Boese, Woodward, \& Bergman, 1994; Farag et al., 2003; Wepener et al., 2001). As such, while gill tissue $\mathrm{Zn}$ concentrations in this study do not reflect significant, site-specific differences in filtered zinc levels, filtered $\mathrm{Zn}$ cannot be ruled out as a contaminant of ecological concern within the Snake River ecosystem.

\subsubsection{Cd}

Gill-bound cadmium concentrations were observed to be significantly elevated in both mainstem Snake River study sites (Figure 5d). However, in contrast to trends observed with gill-binding of copper and lead
(Figure 5a,b), gill-bound cadmium was highest at the moderately impacted SBNF study site. This result may be the consequence of several key differences in the complexation behavior of filtered cadmium. Initially, while DOC concentrations in the Snake River drainage are uniformly low, inputs of DOC from NFS into the Snake River slightly increase DOC concentrations downstream of this confluence (Todd et al., 2005). Increased concentrations of DOC at the SBNF study site lead to increased DOC-binding of filtered metals with high affinities for filtered organic matter (e.g., $\mathrm{Cu}$ and $\mathrm{Pb}$ ), while metals with lower affinity for DOC (e.g., Cd) remain in solution. Finally, all fish gill tissues from the SBNF study site were exposed for the entire duration of the experiment (10 days), while exposure durations at the SANF study ranged from 4 to 10 days. Increased gill exposure times at the SBNF site would allow more time for competitive metal binding interactions to play out at the gill surface.

These predictions are reflected in the results of calculations using the Visual MINTEQ speciation model (HydroGeoLogic \& Allison Geoscience Consultants, 1999). Downstream of the confluence with the North Fork of the Snake River, all modeled filtered metals were predicted to bind to DOC at slightly higher percentages than upstream. At both sites, the free ionic state was the most prevalent species of $\mathrm{Cd}, \mathrm{Mn}$, and $\mathrm{Zn}$, while both $\mathrm{Cu}$ and $\mathrm{Pb}$ were more commonly observed complexed with DOC. Further, at the SBNF site, an increase in $\mathrm{pH}$ had a significant impact on both free $\mathrm{Cu}$ and $\mathrm{Pb}$ concentrations, increasing the percentage of these metals bound to carbonate and hydroxide ions.

Differences in metal-binding behavior have important implications for gill-metal interactions, as free-ion concentrations of metals such as $\mathrm{Cu}$ and $\mathrm{Pb}$ are more drastically reduced by small increases in DOC and $\mathrm{pH}$. For instance, at the SANF site, $\mathrm{Cu}$ free-ions were modeled to be $4 \times$ more prevalent than free $\mathrm{Cd}$, while at the downstream SBNF site, free $\mathrm{Cu}$ was predicted at only $2 \times$ the concentration of free $\mathrm{Cd}$. One important consequence of decreased aqueous concentrations of free $\mathrm{Cu}$ and $\mathrm{Pb}$ would be the decreased competition for $\mathrm{Cd}$ binding at available gill sites, a trend that supports gill-metal binding observed in the data (Figure 5d).

As further evidence supporting elevated Cd-gill binding at the SBNF study site, the Cd-gill $\left(K_{\mathrm{Cd} \text {-Gill }}=\right.$ 8.6) conditional equilibrium binding constant is demonstrably higher than $\mathrm{Cu}$-gill and $\mathrm{Pb}$-gill $\left(K_{\mathrm{Cu}-\text { Gill }}\right.$ 
$\left.=7.4 ; K_{\mathrm{Pb}-\text { Gill }}=6.0\right)($ Playle, 2004). At a site such as SBNF, where other filtered metals (e.g., $\mathrm{Zn}, \mathrm{Cu}, \mathrm{Pb}$ ) are present at moderate concentrations, there are more free sites at the gill/water interface for cadmium to bind to strongly. In contrast, at the SANF site, many filtered metals are present at significantly elevated concentrations, decreasing the likelihood of $\mathrm{Cd}$ contact with vacant gill binding sites.

\subsection{Role of additional stressors}

Stress levels exceeding the tolerance limits of individual organisms can result in impaired physiological function, and can ultimately lead to fish mortality (Wedemeyer, Barton, \& McLeay, 1990). The impacts of added stress on fish stocked in waters contaminated with ARD are evident in this study. Statistical comparisons of fish relative weights from this study suggest that stocked fish experience increasing levels of stress at sites with elevated aqueous filtered metal concentrations. Initially, final relative weights of fed and unfed reference site fish demonstrate that a lack of available food leads to reduced fish relative weight, within the short duration of this experiment. However, fish from both treatments at the most impacted SANF site demonstrated elevated relative weights following exposure, and the net difference between the treatments was insignificant (Table II). This observation is likely attributable to both physiological and behavioral stress responses known to occur in freshwater fish. Environmental stressors, such as exposure to contaminants, have been demonstrated to inhibit food consumption in fish (Bernier \& Peter, 2001; Wendelaar Bonga, 1997). Decreased food consumption was observed, and is a likely explanation for the lack of a statistical difference between feeding treatments. Further, uptake of water by fish attributable to increased stress level has been observed in several studies (Mazeaud, Mazeaud, \& Donaldson, 1977; Woodling, 1993). Elevated stress hormones (catecholamines) increase gill permeability and area, resulting in more water taken up through the fish gill via osmosis (Wendelaar Bonga, 1997). In addition, stressed fish often exhibit "drinking" behavior in freshwater, which can also result in weight gain (Tytler, Tatner, \& Findlay, 1990).

Fish at the moderate SBNF study site appear to demonstrate a reduced stress response due to lower aqueous metal concentrations (Table II). Unlike relative weight decreases observed with unfed fish at the reference site, on average, fish in the unfed treatment at SBNF had unchanged relative weights following 10 days of fasting. In this case, maintenance of relative weight is likely attributable to replacement of lost fish weight with stress-induced water weight. However, in contrast to the SANF study site, SBNF fed fish were observed feeding with regularity, which is reflected by significant relative weight gains.

Although statistical comparison of mortality rates within fed and unfed treatment groups did not reveal a significant relationship at any of the study sites over the 10-day exposure period (correlation insignificant at the 0.01 level), this result was expected as the duration of this experiment was not long enough to act as a significant stressor to expedite experimental fish death. Fasting studies utilizing juvenile rainbow trout demonstrate severe physiological responses only after substantially longer fasting periods (Simpkins, Hubert, Del Rio, \& Rule, 2003).

\section{Summary}

In this study, we investigated the role that ARDderived, waterborne metals play in limiting the survival of stocked rainbow trout in the Snake River, Summit County, Colorado. Theoretical risks to stocked fish cohorts, calculated as hazard quotients using EPA and species-specific toxicity benchmarks, were determined to be elevated at metals-impacted sites. Significantly increased observed mortality rates among cohorts stocked at study sites with elevated metal levels suggests a causative link between these metal concentrations and observed fish deaths. Significantly elevated levels of gill-bound $\mathrm{Cu}, \mathrm{Cd}$, and $\mathrm{Pb}$ in fish at contaminated study sites demonstrate a clear association between the fish and its metals-contaminated environment. Further, significant differences in select stress responses observed in trout stocked at contaminated study sites reflect those that would be predicted from high-level exposure to dissolved metals.

Taken together, these multiple lines of evidence suggest that stocked rainbow trout are significantly impacted by existing dissolved metal concentrations within the sampled reach of the Snake River. Although stocked fish within this reach may be influenced by other factors (angling, migration, dietary metal uptake, etc.), the creation of an on-site, in-situ exposure scenario 
facilitated the isolation of toxic effects specific to aqueous metals exposure. In this study on the Snake River, filtered metals were measured at toxic levels, and these concentrations were observed to limit the survival of stocked experimental fish, suggesting that aqueous metals likely limit the retention of fish stocked in the Snake River from year to year. In this manner, in-situ exposure studies can be utilized to assess the relative role of aqueous contaminant exposure in limiting instream biota, informing future watershed remediation and stream restoration planning within contaminantimpacted watersheds.

Acknowledgments Support for this work was provided through a grant from the U.S. Environmental Protection Agency, Region 8. This work was also supported by the National Science Foundation under grant no. 0108652. Analytical support and expertise was provided by scientists at the USGS Water Chemistry and Geochemistry Analytical Laboratory in Boulder, Colorado, and John Garbarino with the USGS water lab at the Denver Federal Center. Rose Cory, Becky Rule, Chi Yang, Kortney Kirkeby, and the 2003 University of Colorado Research Experience for Undergraduates class provided assistance with fieldwork and labwork. Carol Russell, Kathy Smith, Will Clements, and Lane Wyatt greatly improved this manuscript with their comments. Members of the Snake River Watershed Task Force, including Chuck Tolton and the Keystone Ski Resort, provided critical logistical support and site access.

\section{References}

Anderson, R. O., \& Neumann, R. M. (1996). Length, weight, and associated structural indices. In B. R. Murphy \& D. W. Willis (Eds.), Fisheries techniques-2nd Edition, (pp. 447-482). Bethesda, Maryland, USA: American Fisheries Society.

Avenant-Oldewage, A., \& Marx, H. M. (2000). Bioaccumulation of chromium, copper and iron in the organs and tissue of Clarias gariepinus in the Olifants river, Kruger National Park. Water South Africa, 26(4), 569-582.

Belanger, L. (2002). Source and effect of acid rock drainage in the Snake River watershed, Summit County, Colorado, Masters thesis. Boulder, CO, USA: The University of Colorado.

Bell, R. A., Ogden, N., \& Kramer, J. R. (2002). The biotic ligand model and a cellular approach to class B metal aquatic toxicity. Comparative Biochemistry and Physiology C, 133, 175-188.

Bernier, N. J., \& Peter, R. E. (2001). The hypothalamicpituitary-interrenal axis and the control of food intake in teleost fish. Comparative Biochemistry and Physiology B, 129, 639-644.

Boyer, E. W., McKnight, D. M., Bencala, K. E., Brooks, P. D., Anthony, M. W., Zellweger, G. W., et al. (1999). Streamflow and water-quality characteristics for the upper Snake River and deer creek catchments in Summit County, Colorado:
Water years 1980 to 1990, occasional paper 53. Boulder, CO, USA: Institute of Arctic and Alpine Research.

Camusso, M., Vigano, L., \& Balestrini, R. (1995). Bioconcentration of trace metals in rainbow trout: A field study. Ecotoxicology and Environmental Safety, 31, 133-141.

Chadwick \& Associates (1985). Fish populations of the Snake River, Tenmile Creek and West Tenmile Creek upstream of Dillon reservoir. Littleton, CO, USA.

Chappie, D. J., \& Burton, G. A. (2000). Applications of aquatic and sediment toxicity testing in situ. Soil and Sediment Contamination, 9(3), 219-245.

Dethloff, G. M., Schlenk, D., Hamm, J. T., \& Bailey, H. C. (1999). Alterations in physiological parameters of rainbow trout (Oncorhynchus mykiss) with exposure to copper and copper/zinc mixtures. Ecotoxicology and Environmental Safety, 42, 253-264.

Farag, A. M., Boese, C. J., Woodward, D. F., \& Bergman, H. L. (1994). Physiological changes and tissue metal accumulation in rainbow trout exposed to foodborne and waterborne metals. Environmental Toxicology and Chemistry, 13, 2021-2029.

Farag, A. M., Skaar, D., Nimick, D. A., MacConnell, E., \& Hogstrand, C. (2003). Characterizing aquatic health using salmonid mortality, physiology, and biomass estimates in streams with elevated concentrations of arsenic, cadmium, copper, lead, and zinc in the Boulder river watershed, Montana. Transactions of the American Fisheries Society, 132, 450-467.

Farag, A. M., Stansbury, M. A., Hogstrand, C., MacConnell, E., \& Bergman, H. L. (1995). The physiological impairment of free-ranging brown trout exposed to metals in the Clark Fork river, Montana. Canadian Journal of Fisheries and Aquatic Science, 52, 2038-2050.

Fey, D. L., Church, S. E., Unruh, D. M., \& Bove, D. J. (2001). Water and sediment study of the Snake River watershed, Colorado, Oct. 9-12, 2001, Open-file report 02-0330. Denver, CO, USA: U.S. Geological Survey.

Grosell, M., \& Wood, C. M. (2002). Copper uptake across rainbow trout gills: Mechanisms of atypical entry. Journal of Experimental Biology, 206, 1179-1188.

Guy, C. S., Blankenship, H. L., \& Nielsen, L. A. (1996). Tagging and marking. In B. R. Murphy \& D. W. Willis (Eds.), Fisheries Techniques-2nd Edition (pp. 353-383). Bethesda, Maryland, USA: American Fisheries Society.

Hansen, J. A., Lipton, J., Welsh, P. G., Morris, J., Cacela, D., \& Suedkamp, M. J. (2002). Relationship between exposure duration, tissue residues, growth, and mortality in rainbow trout (Oncorhynchus mykiss) juveniles sub-chronically exposed to copper. Aquatic Toxicology, 58, 175-188.

Heath, A. G. (1987). Water pollution and fish physiology. Boca Raton, Florida, USA: CRC.

Horn, B. (2001). Biotoxicity report, Animas River aquatic toxicity profiles with existing water quality conditions: Appendix 6c. In W. Simon, P. Butler, \& J. R. Owen, (Eds.), Use attainability analysis for the Animas River watershed, Animas River Stakeholders Group, p. 240, appendices, CD-ROM, http://www.waterinfo.org.arsg/.

HydroGeoLogic Inc., \& Allison Geoscience Consultants Inc. (1999). MINTEQA2/PRODEFA2, a geochemical assessment model for Environmental systems: User manual supplement for version 4.0, U.S. Environmental Protection Agency, Athens, Georgia, USA. 
Macdonald, A., Silk, L., Schwartz, M., \& Playle, R. C. (2002). A lead-gill binding model to predict acute lead toxicity to rainbow trout (Oncorhynchus mykiss). Comparative Biochemistry and Physiology C, 133, 227-242.

Marr, J. C. A., Bergman, H. L., Lipton, J., \& Hogstrand, C. (1995). Differences in relative sensitivity of naïve and metalsacclimated brown and rainbow trout exposed to metals representative of the Clark Fork river, Montana. Canadian Journal of Fisheries and Aquatic Science, 52, 2016-2030.

Mazeaud, M. M., Mazeaud, F., \& Donaldson, E. M. (1977). Primary and secondary effects of stress on fish: Some new data with a general review. Transactions of the American Fisheries Society, 106, 201-212.

McKee, D. A., Ordner, M. T., Houston, D., \& Lawrence, A. (1989). Easily constructed, inexpensive cage for aquatic animals, The Progressive Fish-Culturist 51, 166-167.

McKnight, D. M., \& Bencala, K. E. (1990). The chemistry of iron, aluminum, and filtered organic material in 3 acidic, metal-enriched, mountain streams, as controlled by watershed and in-stream processes. Water Resources Research, 26(12), 3087-3100.

McKnight, D. M., \& Feder, G. L. (1984). The ecological effect of acid conditions and precipitation of hydrous metal-oxides in a rocky-mountain stream. Hydrobiologia, 119(2), 129-138.

Mineral Policy Center (1997). Golden dreams, poisoned streams. Washington, D.C., USA.

Paquin, P. R., Gorsuch, J. W., Apte, S., Batley, G. E., Bowles, K. C., Campbell, P. G. C., et al (2002). The biotic ligand model: A historical overview. Comparative Biochemistry and Physiology C, 133, 3-35.

Playle, R. C. (2004). Using multiple metal-gill binding models and the toxic unit concept to help reconcile multiple-metal toxicity results. Aquatic Toxicology, 67, 359-370.

Playle, R. C., Dixon, D. G., \& Burnison, K. (1993). Copper and cadmium binding to fish gills: Modification by filtered organic carbon and synthetic ligands. Canadian Journal of Fisheries and Aquatic Science, 50, 2667-2677.

Reid, S. D., \& McDonald, D. G. (1991). Metal binding activity of the gills of rainbow trout (Oncorhynchus mykiss). Canadian Journal of Fisheries and Aquatic Science, 48, 1061-1068.

Slack, W. T., \& O’Connell, M. T. (1998). Design for a portable, modular stream enclosure/exclosure device. Journal of Freshwater Ecology, 13(2), 193-205.

Simpkins, D. G., Hubert, W. A., Del Rio, C. M., \& Rule, D. C. (2003). Physiological responses of juvenile rainbow trout to fasting and swimming activity: Effects on body composition and condition indices. Transactions of the American Fisheries Society, 132(3), 576-589.
Sorensen, E. M. (1991). Metal Poisoning in Fish. Boston, MA, USA: CRC.

Summerfelt, R. C., \& Smith, L. S. (1990). Anesthesia, surgery, and related techniques. In C. B. Schreck \& P. B. Moyle (Eds.), Methods for Fish Biology (pp. 213-263). Bethesda, Maryland, USA: American Fisheries Society.

Todd, A. S., McKnight, D. M., \& Duren, S. (2005). Water quality characteristics for the Snake River, North Fork of the Snake River, Peru creek, and Deer creek in Summit county, Colorado: 2001 to 2002, Occasional paper 57. Boulder, Colorado, USA: Institute of Arctic and Alpine Research.

Todd, A. S., McKnight, D. M., \& Wyatt, L. (2003). Abandoned mines, mountain sports, and climate variability: Implications for the Colorado tourism economy. Eos, 84(38), 377-386.

Tytler, P., Tatner, M., \& Findlay, C. (1990). The ontogeny of drinking in the rainbow trout, Oncorhynchus mykiss. Journal of Fish Biology, 36, 867-875.

U.S. Environmental Protection Agency (1997). Ecological risk assessment for superfund: Process for designing and conducting ecological risk assessments, EPA-540-R-97006. Washington, D.C., USA: U.S. Environmental Protection Agency.

U.S. Environmental Protection Agency (2002). National Recommended Water Quality Criteria: 2002, EPA-822-R-02047. Washington, D.C., USA: U.S. Environmental Protection Agency.

Van Sickle, J., Baker, J. P., Simonin H. A., Baldigo, B. P., Kretser, W. A., \& Sharpe, W. E. (1996). Episodic acidification of small streams in northeastern United States: Fish mortality in field bioassays. Ecological Applications, 6(2), 408-421.

Wedemeyer, G. A., Barton, B. A., \& McLeay, D. J. (1990). Stress and acclimation. In C. B. Schreck \& P. B. Moyle (Eds.), Methods for Fish Biology (pp. 451-489), Bethesda, Maryland, USA: American Fisheries Society.

Wendelaar Bonga, S. E. (1997). The stress response in fish. Physiological Reviews, 77, 591-625.

Wepener, V., van Vuren, J. H. J., \& du Preez, H. H. (2001). Uptake and distribution of a copper, iron and zinc mixture in gill, liver and plasma of a freshwater teleost, Tilapia sparrmanii. Water South Africa, 27(1), 99-108.

Woodling, J. D. (1993). Survival and mortality of brown trout (Salmo trutta) exposed to in situ acutely toxic concentrations of cadmium and zinc, Ph.D. thesis. Boulder, Colorado, USA: University of Colorado.

Zitko, V., \& Carson, W. G. (1976). Mechanism of effects of water hardness on lethality of heavy-metals to fish. Chemosphere, 5(5), 299-303. 